\title{
Predictive role of heterozygous p.R4810K of RNF213 in the phenotype of Chinese moyamoya disease
}

Yue Wang, MD,* Zhengshan Zhang, MM, * Ling Wei, PhD, * Qian Zhang, MD, Zhengxing Zou, BS, Luping Yang, MD, Desheng Li, MD, Mengke Shang, MD, Cong Han, MM, Michael Mambiya, BS, Xiangyang Bao, MM, Qian Li, MD, Fangbin Hao, BS, Kaili Zhang, MD, Hui Wang, MD, Shan Liu, MD, Mengwei Liu, MD, Fanxin Zeng, MD, Fangfang Nie, MD, Kai Wang, MD, PhD, Wanyang Liu, MD, PhD, and Lian Duan, MD, PhD

Neurology ${ }^{\circledR}$ 2020;94:e678-e686. doi:10.1212/WNL.0000000000008901

\author{
Correspondence \\ Dr. Wang \\ wangkai1964@126.com \\ or Dr. Liu \\ wyliu@cmu.edu.cn \\ or Dr. Duan \\ duanlian307@sina.com
}

\section{Abstract \\ Objective}

Precise genetic analyses were conducted with ring finger protein 213 (RNF213) in relation to a particular clinical phenotype in Chinese patients with moyamoya disease (MMD) to determine whether heterozygosity is responsible for the early-onset and severe form of this disease.

\section{Methods}

A case-control study for RNF213 p.R4810K involving 1,385 Chinese patients with MMD and 2,903 normal control participants was performed. Correlation analyses between genotype and phenotype or different clinical features were also statistically explored.

\section{Results}

An obvious trend was observed: the carrying rate of RNF213 p.R4810K gradually decreased when moving from coastal cities in northeast, north, and east China to southern cities or inland areas. Higher frequencies of p.R4810K were observed in patients with MMD compared with control participants (odds ratio, 48.1; 95\% confidence interval, 29.1-79.6; $p=1.6 \times 10^{-141}$ ). In addition, the onset age of all patients with the GA and AA genotypes were lower than with the GG genotype, and the median onset age was 40.0, 36.0, and 11.5 years with GG, GA, and AA, respectively, thereby confirming that those with GA or AA could acquire MMD during early life stages. Patients with MMD with the GA genotype were more susceptible to posterior cerebral artery (PCA) involvement compared to those with the GG genotype ( $38.4 \%$ vs $23.3 \%, p=8.3 \times$ $\left.10^{-7}\right)$.

\section{Conclusions}

Strong evidence suggests that the carrying rate of RNF213 p.R4810K is closely related MMD risk in China and has given rise to an earlier onset age and more severe PCA involvement.

\footnotetext{
*These authors contributed equally to this work.

From the Department of Nutrition and Food Hygiene, School of Public Health (Y.W., Q.Z., L.Y., M.S., M.M., Q.L., K.Z., S.L., M.L., F.Z., F.N., W.L.), China Medical University, Shenyang. Department of Neurosurgery (Z. Zhang, Z. Zou, D.L., C.H., X.B., F.H., H.W., L.D.), the Fifth Medical Centre, Chinese PLA General Hospital (Former 307th Hospital of the PLA), Beijing; and Department of Neurology (L.W., K.W.), the First Affiliated Hospital of Anhui Medical University, Hefei, China.

Go to Neurology.org/N for full disclosures. Funding information and disclosures deemed relevant by the authors, if any, are provided at the end of the article.

The Article Processing Charge was funded by the National Natural Science Foundation of China (grant no. 81573240) and the Liaoning Provincial Undergraduate Training Program for Innovation and Entrepreneurship of China (grant no. 201810159184).

This is an open access article distributed under the terms of the Creative Commons Attribution-NonCommercial-NoDerivatives License 4.0 (CC BY-NC-ND), which permits downloading and sharing the work provided it is properly cited. The work cannot be changed in any way or used commercially without permission from the journal.
} 


\section{Glossary}

$\mathbf{C I}=$ confidence interval; DSA = digital subtraction angiography; $\mathbf{M M D}=$ moyamoya disease $\mathbf{M R A}=$ magnetic resonance angiography; $\mathbf{O R}$ = odds ratio; $\mathbf{P C A}$ = posterior cerebral artery; SNP = single nucleotide polymorphism.

Moyamoya disease (MMD) is a nonatherosclerotic cerebrovascular structural abnormality that extends to all age groups and occurs worldwide, and a high prevalence has been observed in East Asian descendants. The etiology and pathogenesis of MMD remain unknown. The locus p.R4810K of finger protein 213 (RNF213) was first identified as a pathogenic gene in Japanese familial MMD by studies conducted by Liu et al., ${ }^{1}$ and case-control correlation analyses in an East Asian population showed that p.R4810K was also a pathogenic gene of MMD in China, Japan, and Korea. ${ }^{1}$ Furthermore, some genetic studies have shown that the variant exists in $95 \%$ of Japanese familial cases, $80 \%$ of Japanese and Korean sporadic cases, and 20\% of Chinese sporadic cases. ${ }^{2-9}$ In addition, results regarding the clinical relevance of p.R4810K indicated that the AA genotype corresponded to a significantly earlier onset age and a more severe form of MMD, ${ }^{5,6,10,11}$ and Miyatake et al. ${ }^{6}$ reported that the GA genotype predicts a relatively late onset age and mild clinical course in Japanese patients. It is well-known that MMD is identified as a typical unbalanced disease, ${ }^{12-14}$ and prevalence of clinical characteristics, long-term outcomes, and other specific demographic features of Chinese MMD also differ from those of other ethnicities. ${ }^{15}$ However, potential effects related to RNF213 p.R4810K on various clinical phenotypes of MMD in China have yet to be systematically studied. This study aimed to clarify whether RNF213 p.R4810K was potentially associated with clinical phenotypes based on a large-sample clinical phenotype analysis of Chinese MMD.

\section{Methods}

\section{Sample size and statistical power}

The minor allele frequency of RNF213 p.R4810K was 0.003, with an odds ratio (OR) of 33.65 in Chinese cases ${ }^{16}$; type I error and statistical power was 0.05 and 0.8 , respectively. The calculation indicated that 57 cases and 114 control participants can assure the statistical power of 0.8 . The statistical power was 1.0 according to the sample size of 1,385 cases and 2,903 control participants included in the present study.

\section{Study population}

A total of 1,400 Chinese patients who had been newly or previously diagnosed with $\mathrm{MMD}$ were recruited in this study, from 27 provinces and cities throughout the country. The patients were consecutively enrolled at the Department of Neurosurgery, Fifth Medical Centre, Chinese PLA General Hospital (former 307th Hospital of the PLA), Beijing, and the Department of Neurology, the First Affiliated Hospital of Anhui Medical University, China, from January 2000 to July
2018. MMD diagnosis was determined using digital subtraction angiography (DSA) or magnetic resonance angiography (MRA) or MRI, which were combined with common clinical interviews of relevant and available relatives of patients. Diagnostic criteria for definite MMD diagnosis were based on the criteria of the Research Committee on the Pathology and Treatment of Spontaneous Occlusion of the Circle of Willis, Health Labor Sciences Research Grant for Research on Measures for Intractable Diseases, Japan. ${ }^{17}$ Patients with other basic diseases, such as arteriosclerosis, autoimmune disease, meningitis, or Down syndrome, were excluded from the study. A total of 2,903 unrelated control participants were recruited (1,238 men and 1,665 women, with a mean age of $62.18 \pm$ 14.24 years). Control participants had no typical MMD symptoms, and were not screened by conventional DSA, MRA, $\mathrm{CT}$ angiography, or other tests. The low prevalence of MMD in the Chinese population was assumed not to affect the results of the association study.

To characterize the clinical features of patients with MMD, the clinical records of all previously reviewed cases were collected and examined scrupulously, including hospital charts, clinic notes, and radiologic studies. We ascertained the medical history, onset age, onset symptoms, native location, nationality, diagnosis method, and posterior cerebral artery (PCA) involvement combined with angiographic stage. Angiographic stage was evaluated according to the Suzuki classification.

\section{DNA extraction and single nucleotide polymorphism (SNP) genotyping}

After informed consent was obtained, $10 \mathrm{~mL}$ peripheral vein blood was extracted from available patients with MMD and normal control participants, placed in EDTA $\mathrm{Na}_{4}$ anticoagulant tubes, and stored in a freezer at $-80^{\circ} \mathrm{C}$ until analysis. Genomic DNA was extracted from blood samples with a Blood Genetic DNA Mini Kit (CWBIO, Beijing, China). The concentration of the 4303 DNA was tested by NanoDrop 2000 (Thermo Fisher Scientific, Waltham, MA) and then diluted to working concentrations of $5 \mathrm{ng} / \mu \mathrm{L}$ for genotyping and validation.

Genotyping of p.R4810K in all participants was conducted using TaqMan Probe (TaqMan SNP Genotyping Assays; Applied Biosystems, Foster City, CA) and a QuantStudio 6 Flex Real-Time PCR System (Applied Biosystems). The total system contained $5 \mu \mathrm{L}: 2.0 \mu \mathrm{L}$ purified genomic DNA, $2.5 \mu \mathrm{L}$ TaqPath ProAmp Master Mixes (Applied Biosystems), $0.1 \mu \mathrm{L} 40 \times \mathrm{SNP}$ genotyping assay, and $0.4 \mu \mathrm{L}$ deoxyribonuclease-free water. The appropriate PCR thermal cycling conditions were as follows: maintained for 5 minutes 
for initial denature/enzyme activation, 40 cycles of 5 seconds at $95^{\circ} \mathrm{C}$ for denaturation, and 1 minute at $60^{\circ} \mathrm{C}$ for annealing and extension. After each PCR amplification, an endpoint plate read was conducted using the QuantStudio 6 Flex RealTime PCR System. The genotype of each sample was confirmed based on the fluorescence signals.

\section{Statistical analysis}

PS: Power and Sample Size software was used to calculate the required size. Statistical analyses were performed using SPSS 20.0 (SPSS Inc., Chicago, IL). Patients lacking information for each clinical feature were excluded from the final statistical analyses. In order to compare and analyze differences in onset age in relation to various phenotype variables, we categorized patients into 2 groups: childhood onset ( $0-17$ years old) and adult onset ( $\geq 18$ years old). Difference analyses between the RNF213 genotype and each categorical phenotype variable, such as clinical symptoms or age at onset, unilateral/bilateral distribution of vasculopathy, and Suzuki classification, were performed by $\chi^{2}$ tests $\left(\chi^{2}\right.$ with Fisher exact test was used when warranted). Non-normal distributions or those with $p>0.05$ based on the test of homogeneity of variances with continuous variables were compared using the Mann-Whitney $U$ test and Kruskal-Wallis test. In all analyses, $p$ values were calculated using 2-tailed statistical tests.

\section{Standard protocol approvals, registrations, and patient consents}

The ethical issues involved in this study were examined and approved by the Ethics Committee of China Medical University, the Fifth Medical Centre, Chinese PLA General Hospital, and the First Affiliated Hospital of Anhui Medical University, and all participants and immediate family members signed written informed consent forms.

\section{Data availability}

With the permission of the corresponding authors and their institutions, combined with the relevant documents, all data used for analysis will be shared after ethics approval if requested by other investigators for reasonable purposes of replicating procedures and results.

\section{Results}

\section{Demographics and clinical presentation}

The clinical and demographic characteristics of 1,400 patients with MMD and 2,903 normal control participants are summarized in table 1 . The median age at symptom onset was 35.2 years (range 1-71 years). The female-to-male ratio was 1.2:1. Two age peaks at 5-9 and 45-49 years, with a higher frequency observed in the adult peak, are presented in figure 1. In the present cohort, $97.1 \%$ of patients had bilateral disease, $2.9 \%$ had unilateral $\mathrm{MMD}$, and $1.6 \%$ of patients had a family history of MMD (table 1). TIA was the predominant clinical manifestation, followed by cerebral infarction and cerebral hemorrhage. The majority of patients presented with Suzuki angiographic stage 4 or 5 (61.3\%). In addition, the
Table 1 Sample demographics of patients with moyamoya disease (MMD) and normal control participants

\begin{tabular}{|c|c|c|}
\hline Clinical features & No. of patients $(\%)^{a}$ & $\begin{array}{l}\text { No. of patients } \\
\text { without data }\end{array}$ \\
\hline MMD & 1,400 & \\
\hline Male/female & $635(46.4) / 733$ (53.6) & 32 \\
\hline Age at onset, y & 1,367 & 33 \\
\hline Median (range) & $35.2(1-71)$ & \\
\hline Childhood onset $(<18 y)$ & 266 (19.5) & \\
\hline Adult onset ( $\geq 18 y$ ) & $1,101(80.5)$ & \\
\hline Diagnosis of MMD & 1,400 & \\
\hline Definite & $1,359(97.1)$ & \\
\hline Unilateral & $41(2.9)$ & \\
\hline With family history & $22(1.6)$ & \\
\hline Initial symptoms & 1,365 & 35 \\
\hline Epilepsy & $15(1.1)$ & \\
\hline Incidental & $16(1.2)$ & \\
\hline Ischemic & $1,103(80.8)$ & \\
\hline TIA & $805(59.0)$ & \\
\hline Cerebral infarction & $298(21.8)$ & \\
\hline $\mathrm{CH}$ & 195 (14.3) & \\
\hline Others & $36(2.6)$ & \\
\hline PCA involvement & 343 & \\
\hline Suzuki stage ${ }^{b}$ & 1,918 & 882 \\
\hline 1 & $53(2.8)$ & \\
\hline 2 & $203(10.6)$ & \\
\hline 3 & $334(17.4)$ & \\
\hline 4 & $721(37.6)$ & \\
\hline 5 & $455(23.7)$ & \\
\hline 6 & $152(7.9)$ & \\
\hline Controls & 2,903 & 0 \\
\hline Male/female & $1,238(42.7) / 1,665(57.3)$ & \\
\hline Age, y, mean + SD & $62.18 \pm 14.24$ & \\
\hline Angiographyc & NA & \\
\hline
\end{tabular}

Abbreviations: $\mathrm{CH}=$ cerebral hemorrhage; $\mathrm{NA}=$ not applicable; $\mathrm{PCA}=$ posterior cerebral artery.

a Number of patients (\%) shown for each feature, except for the distribution of ages at onset for all patients.

b Suzuki stage indicates the number of hemispheres.

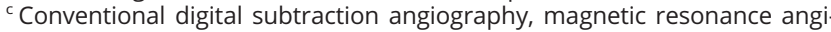
ography, magnetic resonance angiography and other tests.

median initial ages at definite $\mathrm{MMD}$ and unilateral MMD onset were 38.0 and 40.5 years, respectively; this trend is presented in figure $1 \mathrm{~B}$. 
Figure 1 Age distribution patterns in Chinese moyamoya disease
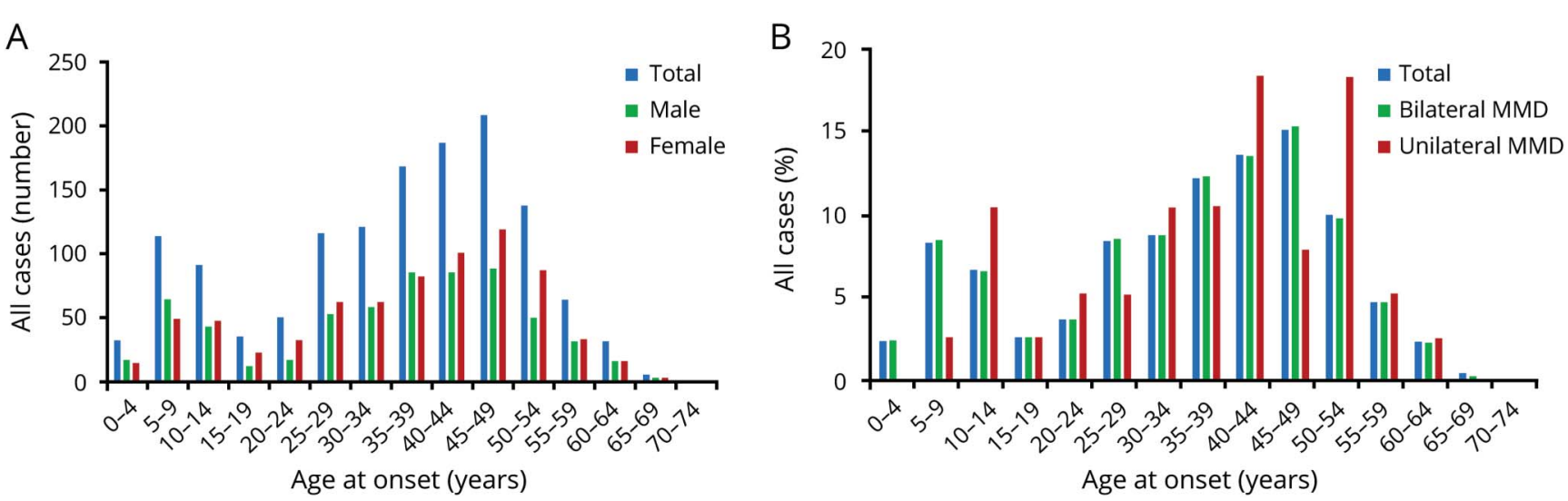

(A) Dual peak distribution of moyamoya disease in all, male, and female groups. (B) The initial age distribution of moyamoya disease in all, bilateral, and unilateral cases.

\section{Higher carrying rate of RNF213 p.R4810K in Eastern and Northeast China}

The birthplace distribution of the 1,352 patients with MMD carrying RNF213 p.R4810K is presented in figure 2. More than half of the cases $(56.0 \%)$ originated from the Central Plains and surrounding regions in China, such as the Henan, Shandong, and Hebei provinces $(26.2 \%, 15.5 \%$, and $14.3 \%$, respectively). The mutation rate in cases carrying RNF213
p.R4810K in our study suggested that higher rates were distributed in coastal provinces in Eastern and Northeast China, such as the Shandong, Jiangsu, and Liaoning provinces (37.2\%, 37.0\%, and $33.3 \%$, respectively).

\section{RNF213 p.R4810K increased the risks of MMD}

We next examined association between RNF213 p.R4810K and MMD. As shown in table 2, both the variant and minor

Figure 2 Distribution of 1,352 cases with moyamoya disease in China

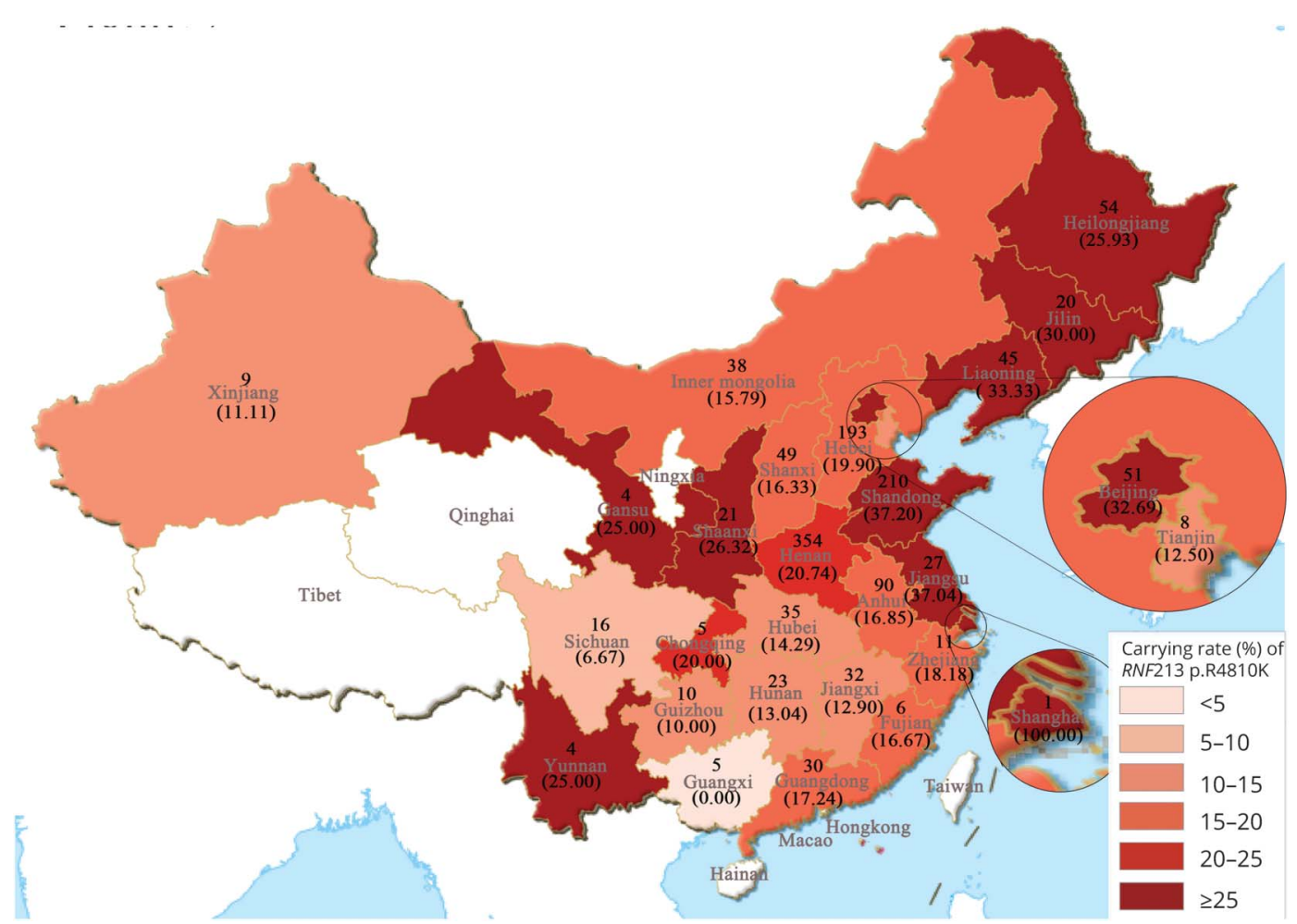

Values given inside and outside parentheses indicate the number of moyamoya patients and the carry rate (\%) of RNF213 p.R4810K in each region, respectively. 
Table 2 Genotype and allele distribution of p.R4810K of RNF213 in patients with moyamoya disease (MMD) and normal control participants

\begin{tabular}{|c|c|c|c|c|c|c|c|c|c|c|c|}
\hline \multirow[b]{2}{*}{ Group } & \multirow[b]{2}{*}{$\begin{array}{l}\text { No. of } \\
\text { participants }\end{array}$} & \multicolumn{3}{|c|}{ Genotype frequency, $\mathrm{n}(\%)$} & \multirow{2}{*}{$\begin{array}{l}p \text { Value } \\
\text { (G/A vs } \\
\text { G/G) }\end{array}$} & \multirow[b]{2}{*}{$\begin{array}{l}p \text { Value } \\
\text { (A/A vs G/G) }\end{array}$} & \multirow[b]{2}{*}{$\begin{array}{l}p \text { Value (A/A + } \\
\text { G/A vs G/G) }\end{array}$} & \multicolumn{2}{|c|}{$\begin{array}{l}\text { Allele frequency, } \\
\text { no (\%) }\end{array}$} & \multirow[b]{2}{*}{$\begin{array}{l}p \\
\text { Value }\end{array}$} & \multirow[b]{2}{*}{$\begin{array}{l}\text { OR } \\
(95 \% \mathrm{Cl})\end{array}$} \\
\hline & & G/G & G/A & $A / A$ & & & & Minor, A & $\begin{array}{l}\text { Major, } \\
\text { G }\end{array}$ & & \\
\hline $\begin{array}{l}\text { All patients with MMD in } \\
\text { this study }\end{array}$ & 1,385 & $1,066(76.1)$ & $313(22.4)$ & $\begin{array}{l}6 \\
(0.5)\end{array}$ & $9.7 \times 10^{-142}$ & $3.9 \times 10^{-4}$ & $1.5 \times 10^{-144}$ & 325 (11.7) & $2,445(88.3)$ & $1.6 \times 10^{-141}$ & $48.1(29.1-79.6)$ \\
\hline $\begin{array}{l}\text { Normal control } \\
\text { participants }\end{array}$ & 2,903 & 2,887 (99.5) & $16(0.5)$ & $0(0.0)$ & & & & $16(0.3)$ & $5,790(99.7)$ & & \\
\hline Age at onset & 1,354 & & & & & & & & & & \\
\hline $\begin{array}{l}\text { Childhood onset } \\
(<18 \mathrm{y})\end{array}$ & 261 & $172(65.9)$ & $85(32.6)$ & $4(1.5)$ & $3.5 \times 10^{-5}$ & $9.0 \times 10^{-3}$ & $9.3 \times 10^{-6}$ & $93(17.8)$ & $429(82.2)$ & $7.6 \times 10^{-6}$ & - \\
\hline Adult onset ( $\geq 18 y$ ) & 1,093 & $867(79.3)$ & $224(20.5)$ & $2(0.2)$ & & & & $228(10.4)$ & $1,958(89.6)$ & & \\
\hline Initial symptoms & 1,316 & & & & & & & 309 & 2,323 & & \\
\hline Epilepsy & 15 & $12(80.0)$ & $2(13.3)$ & $1(6.7)$ & 0.7 & $7.4 \times 10^{-2}$ & 1.0 & $4(13.3)$ & $26(86.7)$ & 0.8 & - \\
\hline Incidental & 16 & $14(87.5)$ & $2(12.5)$ & $0(0.0)$ & 0.5 & 1.0 & 0.5 & $2(6.3)$ & $30(93.7)$ & 0.6 & - \\
\hline Hemorrhagic & 194 & $154(79.4)$ & $40(20.6)$ & $0(0.0)$ & 0.5 & 0.6 & 0.4 & $40(10.3)$ & $348(89.7)$ & 0.4 & - \\
\hline Ischemic & 1,091 & $833(76.4)$ & $253(23.2)$ & $5(0.4)$ & 0.3 & 1.0 & 0.3 & $263(12.1)$ & $1,919(87.9)$ & 0.3 & - \\
\hline TIA & 797 & $602(75.5)$ & $191(24.0)$ & $4(0.5)$ & 0.1 & 1.0 & 0.1 & 199 (12.5) & $1,395(87.5)$ & $3.8 \times 10^{-2}$ & - \\
\hline Cerebral infarction & 294 & $231(78.6)$ & $62(21.1)$ & $1(0.3)$ & 0.5 & 1.0 & 0.5 & $64(10.9)$ & $524(89.1)$ & 0.5 & - \\
\hline $\begin{array}{l}\text { Family history } \\
\text { of MMD }\end{array}$ & 1,385 & & & & & & & & & & \\
\hline Yes & 22 & $12(54.5)$ & $10(45.5)$ & $0(0.0)$ & $1.8 \times 10^{-2}$ & 1.0 & $1.9 \times 10^{-2}$ & $10(22.7)$ & $34(77.3)$ & $3.2 \times 10^{-2}$ & - \\
\hline No & 1,363 & $1,054(77.3)$ & $303(22.2)$ & $6(0.5)$ & & & & 315 (11.6) & $2,411(88.4)$ & & \\
\hline Angiographic findings & 1,385 & & & & & & & & & & \\
\hline Bilateral vasculopathy & 1,345 & $1,032(76.7)$ & $307(22.8)$ & $6(0.5)$ & 0.3 & 1.0 & 0.3 & 319 (11.9) & $2,371(88.1)$ & 0.3 & - \\
\hline Unilateral vasculopathy & 40 & $34(85.0)$ & $6(15.0)$ & $0(0.0)$ & & & & $6(7.5)$ & $74(92.5)$ & & \\
\hline
\end{tabular}

Abbreviations: $\mathrm{Cl}=$ confidence interval; $\mathrm{OR}=$ odds ratio. 
alleles substantially increased the risk for MMD (dominant model, G/A + A/A vs G/G: OR, 54.0; 95\% confidence interval [CI], 32.5-90.0; $p=1.5 \times 10^{-144}$; allele model, A vs G: OR, 48.1; 95\% CI, 29.1-79.6; $\left.p=1.6 \times 10^{-141}\right)$. Although no homozygous mutations were detected in the control samples, the results further confirmed that homozygosity conferred strong effects. Both the variant and minor alleles occurred significantly more frequently in childhood-onset patients than in the adult-onset group ( $34.1 \%$ vs $20.7 \%, p=9.3 \times 10^{-6}$; $17.8 \%$ vs $\left.10.4 \%, p=7.6 \times 10^{-6}\right)$. Regarding the initial manifestation, except for A allele increased the risk of TIA ( $p=3.8$ $\times 10^{-2}$ ); among incidental, hemorrhagic, and ischemic cases, no associations have been found between the p.R4810K genotype or allele and these symptoms. Moreover, compared with patients with MMD with no family history, the frequency of variant p.R4810K genotypes and the minor allele occurred more frequently in patients with family history (dominant model, $p=1.9 \times 10^{-2}$; allele model, $p=3.2 \times 10^{-2}$; table 2 ). However, no observed tendencies were found to correlate with bilateral and unilateral MMD (table 2).

\section{Correlations between RNF213 p.R4810K and clinical phenotype}

The age at onset of all patients with GA and AA was significantly lower than in those with GG $(p<0.05$, figure $3 \mathrm{~A})$. The median age at onset was 11.5, 36.0, and 40.0 in AA, GA, and $\mathrm{GG}$, respectively, and the cumulative incidence of $\mathrm{MMD}$ was higher with AA and GA than with GG in almost all age distributions (figure 3B). Either GA or AA was observed at higher frequencies than GG in patients with childhood onset $\left(27.5 \%\right.$ vs $16.6 \%, p=3.4 \times 10^{-5} ; 66.7 \%$ vs $16.6 \%, p=9.0 \times$ $10^{-3}$, respectively; figure 4). In addition, AA was more common in patients with childhood onset than GA $(66.7 \%$ vs $27.5 \%, p=5.6 \times 10^{-2}$; figure 4$)$, and this further confirmed that patients carrying the A allele could acquire MMD during early life stages. Patients with MMD with a family history were more frequent with GA than in the GG group $(p=1.8 \times$ $\left.10^{-2}\right)$. Furthermore, a significant difference suggested that the AA genotype was more common than GA in those with epilepsy $\left(16.7 \%\right.$ vs $\left.0.7 \%, p=5.8 \times 10^{-2}\right)$, and it was observed that the AA genotype was slightly more common than GG ( $16.7 \%$ vs $1.2 \%, p=0.07$ ); except for epilepsy, other clinical presentations, including incidental, ischemic, and hemorrhagic, have not been found to be significantly different among AA, GA, or GG genotypes. In addition, some patients with MMD with GA were more susceptible to PCA involvement compared to those in the group with GG (38.4\% vs $23.3 \%, p=8.3 \times 10^{-7}$ ).

\section{Discussion}

We confirmed that clear risk of MMD was attributed to RNF213 p.R4810K based on the largest sample of Chinese patients studied to date. More importantly, this is the first study to report the distributions of birthplaces and carrying rates in Chinese patients with MMD and significant differences in genotype-phenotype correlations between people of China and other countries. Both GA and AA could predict an early age at onset and PCA involvement. This is based on the speculation that the effect of founder mutation of RNF213 p.R4810K and both heterozygous and homozygous changes in Chinese MMD onset are uncommon, as the feature differed from that of Japanese patients.

The trend observed in the geographical distribution map of all patients with MMD from 27 Chinese provinces showed a gradual decrease from areas with high carrying rates, such as coastal cities in northeast, north, and east China, to areas with low rates, such as southern cities or inland areas. This corresponds with the assumption that the cities with the highest carrying rates are near Japan or Korea, which may be related to human migration routes, ${ }^{18}$ and further demonstrates effects exhibited by ancestral mutations in the RNF213 p.R4810K gene of MMD. Therefore, the racial significance and genetic background of this disease warrant further clarification of the focus of this study through nationwide or global research to increase the reliability of these findings.

Figure 3 Correlation between p.R4810K genotype and age at onset of moyamoya disease

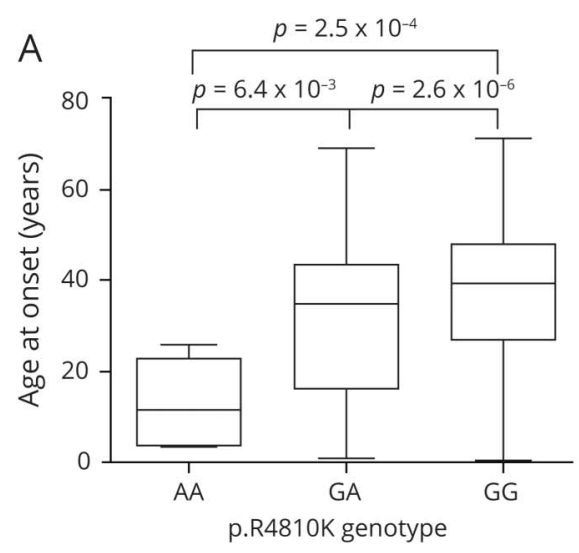

B

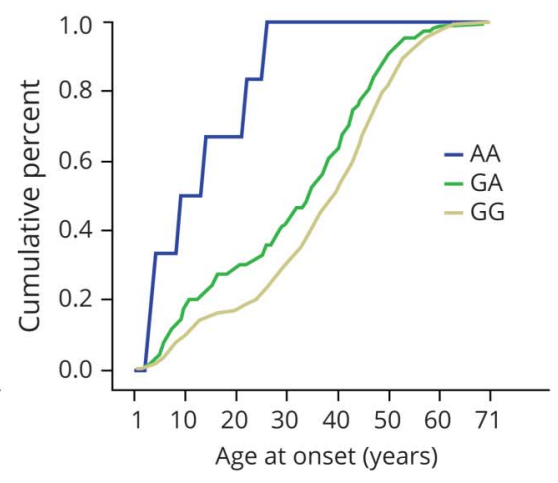

(A) A box plot of the age at onset among 3 patient groups with mutant homozygote (AA), heterozygote $(G A)$, or wild-type $(G G)$ genotypes of the p.R4810K variant. (B) Cumulative incidence curve of the 3 patient groups with homozygote (AA), heterozygote $(\mathrm{GA})$, or wild-type $(\mathrm{GG})$ genotypes of the p.R4810K variant. 


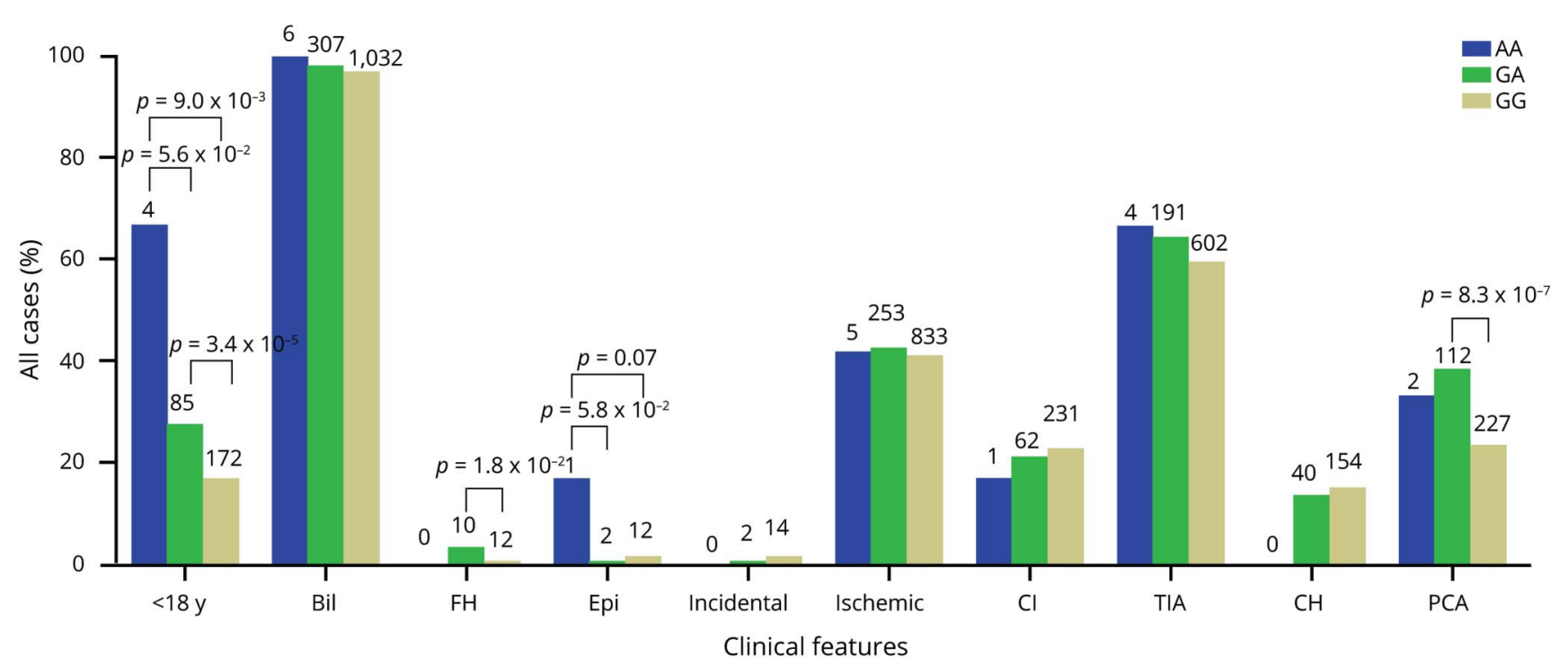

The clinical characteristics of moyamoya disease for the 3 patient groups with homozygote (AA), heterozygote (GA), or wild-type (GG) genotypes of the p. R4810K variant (1,385 patients). The numbers of patients in each group are indicated above the respective bars. $\mathrm{Bil}=$ bilateral vasculopathy; $\mathrm{CH}=\mathrm{cerebral}$ hemorrhage; $\mathrm{Cl}$ = cerebral infarction; Epi = epilepsy; $\mathrm{FH}=$ family history; $\mathrm{PCA}$ = posterior cerebral artery.

A case-control study was also performed and revealed that the carrying rate of RNF213 p.R4810K of MMD was $22.7 \%$, lower than that in the Japanese (90\%) and the Korean (79\%) populations, but these results were similar to that of the Chinese population (23\%) indicated in the reports by Liu et al. ${ }^{1}$ Furthermore, we identified the allele frequency of p.R $4810 \mathrm{~K}$ to be $0.5 \%$ in Chinese people, which was much lower than that of the Japanese (1.36\%) and the Korean (1.36\%) populations and in accordance with the findings of Liu et al. ${ }^{1}$ on distribution of p.R4810K in Eastern and Southeastern Asian populations. ${ }^{19}$ The genetic background of this disease clearly differs among various countries despite each belonging to an Asian population. The lower incidence of MMD in the Chinese population may be due to a lower frequency of the founder mutation. The results of our study also verified the results of the previous study by Liu et al. ${ }^{1}$ and our recent meta-analysis. ${ }^{16}$

It was worth noting that the childhood carrying rate was clearly higher than that of adult patients, and AA groups also displayed the youngest median age at onset. Therefore, we speculated that the homozygous p.R4810K variant of RNF213 may also predict early onset of MMD in Chinese patients, which is similar to the results of studies in some various countries, ${ }^{5,6,10}$ but the largest divergence was found when both GA and AA patients showed significantly younger ages in China than that of GG patients, which suggested that the mutation affected more patients with MMD. Further, Miyatake et al. ${ }^{6}$ reported that GA predicted a relatively late onset age and clinical course in Japanese patients. Most Chinese patients with MMD with AA (66.7\%) had TIA at initial presentation; this was unlike Japanese patients, who displayed infarction as the most common presentation in the AA group. ${ }^{5}$ No significant difference was found in the severity of initial symptoms between patients carrying the RNF213 p.R4810K mutation and noncarriers. We originally analyzed the relationship between RNF213 p.R4810K and initial symptoms and found that the A allele increased the risk of TIA; however, a significant result was not obtained. Nevertheless, a low percentage of incidental cases were found in this study, perhaps due to different factors. Regardless, these patients should remain the focus of further study, and angiography or MRA, combined with routine DSA, are necessary to identify additional patients.

Moreover, patients with a family history of MMD were more likely to carry the p.R4810K variant in the current study, and this result supported the results of some previous studies. ${ }^{1,2,20}$ Interestingly, the ages of patients with family history were largely concentrated in the 5-9 age range, and these results coincided with that of Zhang et al., ${ }^{21}$ who found that Chinese familial MMD can occur in patients and their third-degree relatives, of which firstdegree relatives are the most affected. Doctors should pay more attention to the family histories of patients with MMD during the process of diagnosis and expand the scope of screening in high-risk groups, especially younger patients. Nevertheless, posterior circulation is a significant collateral arterial route in the earlier stages of $\mathrm{MMD}^{22}$ and is treated as an important predictor for outcomes of patients with MMD. ${ }^{23,24}$ Several studies have demonstrated that the prevalence of PCA involvement in MMD was $18.1 \%-36.2 \%$ in pediatric patients and $21.2 \%-43.4 \%$ in adult patients at initial diagnosis. ${ }^{24-26}$ Our study showed similar results. In addition, Kim and $\mathrm{Kim}^{11}$ found that PCA 
territorial involvement was more frequently observed in RNF213-positive patients than in RNF213-negative patients. Our results further showed that GA patients were more susceptible to PCA involvement than were wild-type patients. This result differed from that of Miyatake et al. ${ }^{5}$; however, we considered that this may be attributed to differences in genotype distribution between Chinese and Japanese patients or the limited number of AA patients in China, so we concluded that the p.R4810K mutation may cause more severe and wider vasculopathy in the brain. Meanwhile, other poor prognostic factors, such as cerebral infarction, were more commonly identified in Japanese and Korean patients with AA, ${ }^{5,10}$ but we detected epilepsy more frequently in Chinese patients. Therefore, future research should further expand the sample size to verify the reliability of these results, especially in patients with the AA genotype.

This study had certain limitations that should be noted. First, we only analyzed relationships between RNF213 p.R4810K and clinical features. However, MMD is a comof inheritance, and single gene-focused study cannot sufficiently elucidate its genetic susceptibility; meanwhile, the function of single genes or the clinical features of MMD may be dependent on the synergy of other genetic variations. Second, this is a study based on a single-center hospital, so selection bias is unavoidable. Third, we have chosen the Suzuki staging system to classify the severity of $\mathrm{MMD},{ }^{27,28}$ but it has been reported that this system was based mainly on intensified serial angiographic changes or decreases in moyamoya vessels, and clear disadvantages remain in the accuracy of classification based on angiographic findings. ${ }^{29,30}$ Therefore, the staging system defined by Mugikura et al. ${ }^{30}$ should be used for precise staging in the future.

To our knowledge, this study concerning the relationship between the RNF213 p.R4810K genotype and clinical phenotype was based on the largest case sample globally and the largest range in China to date. From the perspective of our research results, either homozygous or heterozygous RNF213 p.R4810K can predict the early age at onset of MMD and PCA involvement in Chinese patients with MMD. Continuous and timely follow-up observation may be helpful for clinicians and families to implement effective measures for slowing disease progression and further prevent the occurrence of adverse outcomes to the greatest extent prior to the diagnosis of new definite clinical cases.

\section{Acknowledgment}

The authors thank the participants for their cooperation in this study.

\section{Study funding}

Supported by the National Natural Science Foundation of China (grant no. 81573240) and the Liaoning Provincial plex disease with genetic heterogeneity and a classic pattern

Undergraduate Training Program for Innovation and Entrepreneurship of China (grant no. 201810159184).

\section{Disclosure}

Y. Wang, Z. Zhang, L. Wei, Q. Zhang, Z. Zou, L. Yang, D. Li, M. Shang, C. Han, M. Mambiya, X. Bao, L. Qian, F. Hao, K. Zhang, H. Wang, S. Liu, M. Liu, F. Zeng, F. Nie, and K. Wang report no disclosures relevant to the manuscript. W. Liu is funded by the National Natural Science Foundation of China (grant no. 81573240) and the Liaoning Provincial Undergraduate Training Program for Innovation and Entrepreneurship of China (grant no. 201810159184). L. Duan reports no disclosures relevant to the manuscript. Go to Neurology.org/ $\mathrm{N}$ for full disclosures.

\section{Publication history}

Received by Neurology February 6, 2019. Accepted in final form August 16, 2019.

\begin{tabular}{|c|c|c|c|}
\hline Name & Location & Role & Contribution \\
\hline $\begin{array}{l}\text { Yue Wang, } \\
\text { MD }\end{array}$ & $\begin{array}{l}\text { China Medical } \\
\text { University, } \\
\text { Shenyang }\end{array}$ & Author & $\begin{array}{l}\text { Study concept and } \\
\text { design, analysis of the } \\
\text { genetic data, data } \\
\text { integrity, interpretation } \\
\text { of the data, statistical } \\
\text { analysis, and drafting/ } \\
\text { revising the manuscript }\end{array}$ \\
\hline $\begin{array}{l}\text { Zhengshan } \\
\text { Zhang, MM }\end{array}$ & $\begin{array}{l}\text { Chinese PLA } \\
\text { General Hospital, } \\
\text { Beijing }\end{array}$ & Author & $\begin{array}{l}\text { Major role in the } \\
\text { acquisition of data, } \\
\text { designed and } \\
\text { conceptualized study }\end{array}$ \\
\hline $\begin{array}{l}\text { Ling Wei, } \\
\text { PhD }\end{array}$ & $\begin{array}{l}\text { First Affiliated } \\
\text { Hospital of Anhui } \\
\text { Medical University, } \\
\text { Hefei }\end{array}$ & Author & Data collection \\
\hline $\begin{array}{l}\text { Qian } \\
\text { Zhang, MD }\end{array}$ & $\begin{array}{l}\text { China Medical } \\
\text { University, } \\
\text { Shenyang }\end{array}$ & Author & $\begin{array}{l}\text { Data integrity, } \\
\text { interpretation of the } \\
\text { data }\end{array}$ \\
\hline $\begin{array}{l}\text { Zhengxing } \\
\text { Zou, BS }\end{array}$ & $\begin{array}{l}\text { Chinese PLA } \\
\text { General Hospital, } \\
\text { Beijing }\end{array}$ & Author & $\begin{array}{l}\text { Analysis of the clinical } \\
\text { data and sample } \\
\text { collection }\end{array}$ \\
\hline $\begin{array}{l}\text { Luping } \\
\text { Yang, MD }\end{array}$ & $\begin{array}{l}\text { China Medical } \\
\text { University, } \\
\text { Shenyang }\end{array}$ & Author & $\begin{array}{l}\text { Analysis of the genetic } \\
\text { data, data integrity, } \\
\text { interpretation of the } \\
\text { data, statistical analysis }\end{array}$ \\
\hline $\begin{array}{l}\text { Desheng Li, } \\
\text { MD }\end{array}$ & $\begin{array}{l}\text { Chinese PLA } \\
\text { General Hospital, } \\
\text { Beijing }\end{array}$ & Author & $\begin{array}{l}\text { Analysis of the clinical } \\
\text { data and sample } \\
\text { collection }\end{array}$ \\
\hline $\begin{array}{l}\text { Mengke } \\
\text { Shang, MD }\end{array}$ & $\begin{array}{l}\text { China Medical } \\
\text { University, } \\
\text { Shenyang }\end{array}$ & Author & $\begin{array}{l}\text { Data integrity, } \\
\text { interpretation of the } \\
\text { data, and drafting/ } \\
\text { revising the manuscript }\end{array}$ \\
\hline $\begin{array}{l}\text { Cong Han, } \\
\text { MM }\end{array}$ & $\begin{array}{l}\text { Chinese PLA } \\
\text { General Hospital, } \\
\text { Beijing }\end{array}$ & Author & $\begin{array}{l}\text { Analysis of the clinical } \\
\text { data and sample } \\
\text { collection }\end{array}$ \\
\hline $\begin{array}{l}\text { Michael } \\
\text { Mambiya, } \\
\text { BS }\end{array}$ & $\begin{array}{l}\text { China Medical } \\
\text { University, } \\
\text { Shenyang }\end{array}$ & Author & $\begin{array}{l}\text { Data integrity, } \\
\text { interpretation of the } \\
\text { data, and drafting/ } \\
\text { revising the manuscript }\end{array}$ \\
\hline
\end{tabular}


Appendix (continued)

\begin{tabular}{|c|c|c|c|}
\hline Name & Location & Role & Contribution \\
\hline $\begin{array}{l}\text { Xiangyang } \\
\text { Bao, MM }\end{array}$ & $\begin{array}{l}\text { Chinese PLA } \\
\text { General Hospital, } \\
\text { Beijing }\end{array}$ & Author & Data collection \\
\hline Qian Li, MD & $\begin{array}{l}\text { China Medical } \\
\text { University, } \\
\text { Shenyang }\end{array}$ & Author & $\begin{array}{l}\text { Data integrity, } \\
\text { interpretation of the } \\
\text { data, and drafting/ } \\
\text { revising the manuscript }\end{array}$ \\
\hline $\begin{array}{l}\text { Fangbin } \\
\text { Hao, BS }\end{array}$ & $\begin{array}{l}\text { Chinese PLA } \\
\text { General Hospital, } \\
\text { Beijing }\end{array}$ & Author & Data collection \\
\hline $\begin{array}{l}\text { Kaili Zhang, } \\
\text { MD }\end{array}$ & $\begin{array}{l}\text { China Medical } \\
\text { University, } \\
\text { Shenyang }\end{array}$ & Author & Analyzed the data \\
\hline $\begin{array}{l}\text { Hui Wang, } \\
\text { MD }\end{array}$ & $\begin{array}{l}\text { Chinese PLA } \\
\text { General Hospital, } \\
\text { Beijing }\end{array}$ & Author & Data collection \\
\hline $\begin{array}{l}\text { Shan Liu, } \\
\text { MD }\end{array}$ & $\begin{array}{l}\text { China Medical } \\
\text { University, } \\
\text { Shenyang }\end{array}$ & Author & $\begin{array}{l}\text { Analysis of the genetic } \\
\text { data }\end{array}$ \\
\hline $\begin{array}{l}\text { Mengwei } \\
\text { Liu, MD }\end{array}$ & $\begin{array}{l}\text { China Medical } \\
\text { University, } \\
\text { Shenyang }\end{array}$ & Author & Data collection \\
\hline $\begin{array}{l}\text { Fanxin } \\
\text { Zeng, MD }\end{array}$ & $\begin{array}{l}\text { China Medical } \\
\text { University, } \\
\text { Shenyang }\end{array}$ & Author & $\begin{array}{l}\text { Analysis of the genetic } \\
\text { data }\end{array}$ \\
\hline $\begin{array}{l}\text { Fangfang } \\
\text { Nie, MD }\end{array}$ & $\begin{array}{l}\text { China Medical } \\
\text { University, } \\
\text { Shenyang }\end{array}$ & Author & Data collection \\
\hline $\begin{array}{l}\text { Kai Wang, } \\
\text { MD, PhD }\end{array}$ & $\begin{array}{l}\text { First Affiliated } \\
\text { Hospital of Anhui } \\
\text { Medical University, } \\
\text { Hefei }\end{array}$ & Author & $\begin{array}{l}\text { Analysis of the clinical } \\
\text { data and sample } \\
\text { collection }\end{array}$ \\
\hline $\begin{array}{l}\text { Wanyang } \\
\text { Liu, MD, } \\
\text { PhD }\end{array}$ & $\begin{array}{l}\text { China Medical } \\
\text { University, } \\
\text { Shenyang }\end{array}$ & Author & $\begin{array}{l}\text { Drafting and revision for } \\
\text { intellectual content }\end{array}$ \\
\hline $\begin{array}{l}\text { Lian Duan, } \\
\text { MD, PhD }\end{array}$ & $\begin{array}{l}\text { Chinese PLA } \\
\text { General Hospital, } \\
\text { Beijing }\end{array}$ & Author & $\begin{array}{l}\text { Drafting and revision for } \\
\text { intellectual content }\end{array}$ \\
\hline
\end{tabular}

\section{References}

1. Liu W, Morito D, Takashima S, et al. Identification of RNF213 as a susceptibility gene for moyamoya disease and its possible role in vascular development. PLoS One 2011;6:e22542.

2. Kamada F, Aoki Y, Narisawa A, et al. A genome-wide association study identifies RNF213 as the first Moyamoya disease gene. J Hum Genet 2011;56:34-40.

3. Wu Z, Jiang H, Zhang L, et al. Molecular analysis of RNF213 gene for moyamoya disease in the Chinese Han population. PLoS One 2012;7:e48179.

4. Wang X, Zhang Z, Liu W, et al. Impacts and interactions of PDGFRB, MMP-3, TIMP2, and RNF213 polymorphisms on the risk of Moyamoya disease in Han Chinese human subjects. Gene 2013;526:437-442.
5. Miyatake S, Miyake N, Touho H, et al. Homozygous c.14576G>A variant of RNF213 predicts early-onset and severe form of moyamoya disease. Neurology 2012;78: 803-810.

6. Miyatake S, Touho H, Miyake N, et al. Sibling cases of moyamoya disease having homozygous and heterozygous c.14576G $>$ A variant in RNF213 showed varying clinical course and severity. J Hum Genet 2012;57:804-806.

7. Miyawaki S, Imai H, Takayanagi S, Mukasa A, Nakatomi H, Saito N. Identification of a genetic variant common to moyamoya disease and intracranial major artery stenosis/occlusion. Stroke 2012;43:3371-3374.

8. Miyawaki S, Imai H, Shimizu M, et al. Genetic variant RNF213 c.14576G>A in various phenotypes of intracranial major artery stenosis/occlusion. Stroke 2013;44: 2894-2897.

9. Cecchi AC, Guo D, Ren Z, et al. RNF213 rare variants in an ethnically diverse population with Moyamoya disease. Stroke 2014;45:3200-3207.

10. Kim EH, Yum MS, Ra YS, et al. Importance of RNF213 polymorphism on clinical features and long-term outcome in moyamoya disease. J Neurosurg 2016;124: 1221-1227.

11. Kim WH, Kim SD. Posterior circulation involvement and collateral flow pattern in moyamoya disease with the RNF213 polymorphism. Childs Nerv Syst 2019;35: 309-314.

12. Kuroda S, Houkin K. Moyamoya disease: current concepts and future perspectives. Lancet Neurol 2008;7:1056-1066.

13. Miao W, Zhao PL, Zhang YS, et al. Epidemiological and clinical features of Moyamoya disease in Nanjing, China. Clin Neurol Neurosurg 2010;112:199-203.

14. Fujimura M, Sonobe S, Nishijima Y, et al. Genetics and biomarkers of moyamoya disease: significance of RNF213 as a susceptibility gene. J Stroke 2014;16: 65-72.

15. Duan L, Bao XY, Yang WZ, et al. Moyamoya disease in China: its clinical features and outcomes. Stroke 2012;43:56-60.

16. Wang Y, Mambiya M, Li Q, et al. RNF213 p.R4810K polymorphism and the risk of moyamoya disease, intracranial major artery stenosis/occlusion, and quasi-moyamoya disease: a meta-analysis. J Stroke Cerebrovasc Dis 2018;27:2259-2270.

17. Guidelines for diagnosis and treatment of moyamoya disease (spontaneous occlusion of the circle of Willis). Neurol Med Chir 2012;52:245-266.

18. Abdulla MA, Ahmed I, Assawamakin A, et al. Mapping human genetic diversity in Asia. Science 2009;326:1541-1545.

19. Liu W, Hitomi T, Kobayashi H, Harada KH, Koizumi A. Distribution of moyamoya disease susceptibility polymorphism p.R4810K in RNF213 in East and Southeast Asian populations. Neurol Med Chir 2012;52:299-303.

20. Zhang Q, Liu Y, Zhang D, et al. RNF213 as the major susceptibility gene for Chinese patients with moyamoya disease and its clinical relevance. J Neurosurg 2017;126: 1106-1113.

21. Zhang Z, Zhang R, Duan L. Clinical features of familial moyamoya disease in China Int J Cerebrovasc Dis 2016:114-116.

22. Miyamoto S, Kikuchi H, Karasawa J, Nagata I, Ikota T, Takeuchi S. Study of the posterior circulation in moyamoya disease: clinical and neuroradiological evaluation. J Neurosurg 1984;61:1032-1037.

23. Mugikura S, Takahashi S, Higano S, et al. The relationship between cerebral infarction and angiographic characteristics in childhood moyamoya disease. AJNR Am J Neuroradiol 1999;20:336-343.

24. Yamada I, Himeno Y, Suzuki S, Matsushima Y. Posterior circulation in moyamoya disease: angiographic study. Radiology 1995;197:239-246.

25. Mugikura S, Higano S, Shirane R, Fujimura M, Shimanuki Y, Takahashi S. Posterior circulation and high prevalence of ischemic stroke among young pediatric patients with moyamoya disease: evidence of angiography-based differences by age at diagnosis. AJNR Am J Neuroradiol 2011;32:192-198.

26. Funaki T, Takahashi JC, Takagi Y, et al. Impact of posterior cerebral artery in volvement on long-term clinical and social outcome of pediatric moyamoya disease. J Neurosurg Pediatr 2013;12:626-632.

27. Suzuki J, Kodama N. Moyamoya disease: a review. Stroke 1983;14:104-109.

28. Suzuki J, Takaku A. Cerebrovascular "moyamoya" disease: disease showing abnormal net-like vessels in base of brain. Arch Neurol 1969;20:288-299.

29. Hishikawa T, Tokunaga K, Sugiu K, Date I. Assessment of the difference in posterior circulation involvement between pediatric and adult patients with moyamoya disease. J Neurosurg 2013;119:961-965.

30. Mugikura S, Takahashi S, Higano S, Shirane R, Sakurai Y, Yamada S. Predominant involvement of ipsilateral anterior and posterior circulations in moyamoya disease. Stroke 2002;33:1497-1500. 


\section{Neurology}

\section{Predictive role of heterozygous p.R4810K of RNF213 in the phenotype of Chinese moyamoya disease}

Yue Wang, Zhengshan Zhang, Ling Wei, et al.

Neurology 2020;94;e678-e686 Published Online before print January 16, 2020

DOI 10.1212/WNL.0000000000008901

\section{This information is current as of January 16, 2020}

\section{Updated Information \&} Services

References

Subspecialty Collections

Permissions \& Licensing

Reprints including high resolution figures, can be found at: http://n.neurology.org/content/94/7/e678.full

This article cites 29 articles, 10 of which you can access for free at: http://n.neurology.org/content/94/7/e678.full\#ref-list-1

This article, along with others on similar topics, appears in the following collection(s):

Association studies in genetics

http://n.neurology.org/cgi/collection/association_studies_in_genetics Case control studies

http://n.neurology.org/cgi/collection/case_control_studies

Information about reproducing this article in parts (figures,tables) or in its entirety can be found online at:

http://www.neurology.org/about/about_the_journal\#permissions

Information about ordering reprints can be found online:

http://n.neurology.org/subscribers/advertise

Neurology ${ }^{\circledR}$ is the official journal of the American Academy of Neurology. Published continuously since 1951, it is now a weekly with 48 issues per year. Copyright Copyright ( 2020 The Author(s). Published by Wolters Kluwer Health, Inc. on behalf of the American Academy of Neurology.. All rights reserved. Print ISSN: 0028-3878. Online ISSN: 1526-632X.

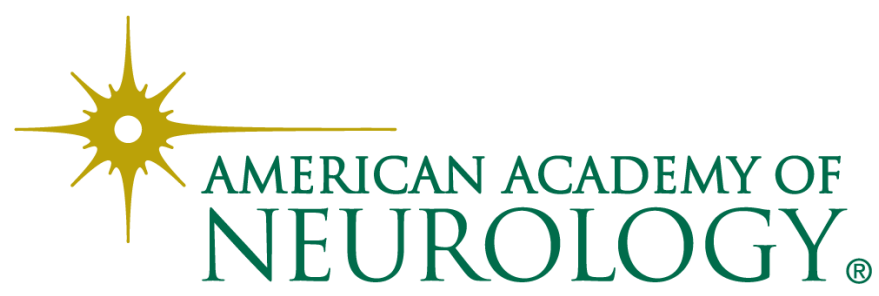

